\title{
Implementation of Thematic Learning in Increasing Cognitive Development and Children Language in Raudhatul Atfhal Rahmat Islamiyah Medan
}

\author{
Tien Rafida ${ }^{1}$, Jamilah ${ }^{2}$ \\ ${ }^{1,2}$ FITK UIN SU Medan, Indonesia \\ titinrafida@gmail.com
}

Keywords

Thematic Learning; Cognitive Development; Children Language

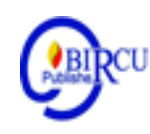

\section{Introduction}

Early childhood is a golden age which is a period conducive to developing various physical, cognitive, linguistic, social emotional and spiritual abilities as a provision for the next life. This golden age period is a critical period in which the child needs the right stimuli to achieve perfect maturity. Critical meaning here is very influential in the success of the next 
period, with other words if this critical period does not get the right stimulus in the form of exercise or learning process, it is estimated that children will experience difficulties in the next developmental period.

Thematic learning is learning that is useful, interesting, meaningful, and appropriate for students in early primary school (SD) classes. The teacher must be creative in teaching, various approaches in learning need to be considered by the teacher so that learning can proceed in accordance with the objectives to be achieved. (Simorangkir, 2019)

The main characteristic of thematic learning is learning activities without putting a burden on children, so that the concept of learning at an early age is dominant by playing firmly held and learning activities are more emphasized on children's creativity. Thematic learning is the packaging of lessons in a theme that contains several areas of competence that children learn, so that the abilities acquired by children can be diverse, not necessarily the same for each child. The uniqueness of each child must be respected. Some children may be able to read ahead of other children and that is not a concern. Every child doesn't have to take the same path in learning something.

Thematic learning is a way to not limit children in a "subject", in learning something. For example, while learning to sing someone the child learns the alphabet. Or while learning to know animals he also learns to color. Learn to recognize wild plants while hiking. Learning many things at once in one big theme trains to connect what he has learned into a large, complete picture. Besides the child's boredom for a subject can be reduced because of the many variations. Maybe a child does not like to count, but because counting is packaged in a game, children become interested in the game.

\section{Review of Literature}

Thematic learning is defined as a learning activity by integrating the material of several subjects into one discussion theme. The same thing was also expressed by Sutirjo and Mamik (2004) stating thematic learning is an attempt to integrate knowledge, skills, values or attitudes of learning and creative thinking using themes.

Meanwhile, Tukimo et-al (2005) explain thematic learning as integrated learning through themes as a unifier by combining several subjects at once that can be linked to one another. Furthermore, Tukimo et al explained that thematic learning is intended to provide meaningful experiences to students, because in students in understanding the various concepts they learn through direct experience and connecting with the concepts they have mastered.

The characteristics of thematic learning as revealed by the Ministry of National Education (2006) are: (1) learning experiences and activities are very relevant to the level of development and needs of students, (2) the activities chosen in the implementation of thematic learning are based on students' interests and needs, (3) learning activities will be more meaningful and memorable for students so that learning outcomes can last longer, (4) help develop students' thinking skills, (5) present pragmatic learning activities in accordance with problems that are often encountered by students in their environment, and (6) develop students' social skills, such as cooperation, tolerance, communication, and responsiveness to the ideas of others.

Cognitive development, Piaget distinguishes it in four stages, namely: (1) The sensorimotor stage (age $0-2$ years) is the stage where babies build understanding of the 
world by coordinating sensory experiences and physical actions. The baby steps forward from instinctual and reflexive actions at birth to symbolic thinking towards the end of this stage, (2) The pre-operational stage (ages 2-7 years) is the stage at which the child begins to represent the world with words and pictures. These words and images reflect an increase in symbolic thinking and go beyond sensory information connections and physical actions. At this pre-operational stage the child shows a characteristic of thinking called centration (focusing / focusing attention on one characteristic by ignoring the other characteristics). The pre-operational stage is divided into two sub-stages: (a) symbolic sub-stages, and (b) substages of intuitive thought. The symbolic sub-step (age 2-4 years) is the stage where the child can mentally begin to represent an object that is absent. The intuitive thinking stage (ages 4 7 years) is the stage where children begin to use primitive reasoning and want to know the answers to all questions, (3) The concrete operational stage (ages 7 - 11 years) is the stage at which children can reason logically about concrete events and are able to classify objects into different groups, and (4) The formal operational stage (11 years - until adulthood) is the stage where children think in a more abstract, idealistic and logical way. At this stage a child makes a plan to solve a problem and systematically tests the solution, in this case Piaget calls it the term hypothetical deductive reasoning (Santrock, 2008).

Related to children's language development, Lenneberg explained as quoted by Yamin and Sanan (2010) following and in accordance with their non-negotiable biological development. A child cannot be forced or triggered in any way to be able to say / say something, if only biological progress has not been possible to utter a level. Conversely, if only a child is biologically able to say / say something, then he will not be prevented / detained not to say / say it.

Child language development according to Vygotsky in 3 stages, namely: (1) the first stage, namely the external stage is the stage of thinking with language called speaking externally, in this case the source of children's thinking comes from outside themselves with the main source coming from adults, (2) the second stage is the egocentric stage is the stage where adult speech is no longer a requirement, with the typical voice of the child speaking as his own way of thinking, and (3) the third stage is the stage of speaking internally where the child fully lives his thought process (Moeslichatoen, 2004) .

Language competence or ability is the ability of language to express ideas about themselves and understand others and learn new words or other languages (Yus, 2011). Meanwhile, according to Yamin and Sanan (2010) explained that language development, competencies and expected outcomes are children able to use language as an understanding of passive language and can communicate effectively which is useful for thinking and learning well.

Allen and Marotz (2010) describe the characteristics of language development for children aged 5 years: mastering 1500 vocabulary or more, telling stories that he already knows when looking at pictures in books, mentioning the usefulness of something, recognizing and mentioning four to eight colors, understanding simple jokes, make up puzzles, say sentences with 5-7 words, can also be longer sentences, mention the name of the city where you live, birthday and parent's name, answer the phone, say sentences that are almost completely understandable and use said exactly. 


\section{Research Method}

The study was conducted at Raudhatul Atfhal Rahmat Islamiyah Medan. The method used is a qualitative research method. Data sources are the principal, teachers and students. Data retrieved through observation, documentation, and interviews. Data are analyzed based on data reduction, data presentation, and onclusions.

\section{Discussion}

Data collected in the field and also based on the results of evaluations conducted by teachers of children's cognitive and language levels are increasing through the application of thematic learning. The increase was marked by the number of children doing questioning activities, telling something they saw, telling their work and asking about the meaning and purpose of a picture more than ever before. Likewise, children's reading ability significantly increased both in terms of individual ability of children to read and the number of children who improve their reading ability compared to before.

Children's activities in learning activities on the theme of air water and fire more than in previous learning. If the thematic learning on the theme of children's work answers more questions from the teacher then on the theme of water, air and fire the cognitive and language development of the child to ask more questions is increasing. Dialogue between children and teachers often occurs. Children are enthusiastic to ask something that they see and hear.

Implementation of the game on the theme of air water, more fire is done in the game room and outside the classroom when compared to previous fires. Games outside the game and outside the classroom provide different situations so that the children's cognitive and language also develop. By doing games outside the classroom the child is closer to the actual situation especially the theme carried is "water, air and fire" so that it encourages more children to explore with the natural surroundings.

The giving of praise and appreciation has a positive impact on children, from the observations it can be seen that children who are given praise and appreciation for their success lead to enthusiasm to create even better, while those who have not succeeded are still given encouragement in the form of praise and appreciation by the teacher.

In addition, a variety of play equipment and also in accordance with the interests of children further increase the desire to be creative and tell stories more actively. The desire of children to tell stories about the drawings they made is quite high, it can be seen from the enthusiasm of the children to scramble to tell each other about the pictures they have seen and made, the enthusiasm of children is quite high when some pictures are designed in the classroom according to the theme carried. The children ask each other questions and explain to the teacher and their friends about what they see. The desire of children to try to imitate letters and words as well as the desire to know the reading of words and simple sentences is clearly visible.

Thematic learning on the theme of communication tools generally shows that children are accustomed to the actions taken by the teacher in learning activities through games that are varied because they have been introduced before. The cognitive and language of children has increased from before, this can be observed from the results of the evaluation of children not visible more timid about asking or answering teacher questions.

The game of remembering names is done by the teacher by using a number of more business cards than before to 15-20. The learning activities are not much different, namely 
the child mentions some names and forms of their activities, the teacher tells the child to read the business cards that have written the activities. The game of remembering this name also uses media card images and panel boards. When the teacher tells a story and mentions objects and words by going around and using a picture card affixed to the panel board, the child's attention arises and the child is interested in paying attention to the picture and sometimes between them guess the picture.

Achievement games are done by the teacher through science play activities, namely conducting simple experiments such as conducting color mixing experiments, objects that are brought close to magnets, objects dropped into water. Children in the activities of achievement games hold their own experiment tools, so that when the game is implemented they can participate. At the end of this achievement game the teacher gives praise and appreciation for all children even though there are children who are not quite right and are able to complete their assignments. The aim of this achievement game is that the child grows his creativity and independence in finding something that the teacher commands.

The motion game on the theme of communication tools is done by the teacher by playing the role, in this case the teacher asks the child to play the role in accordance with the theme carried, namely the theme of "communication tools". The role playing done is "being a television broadcaster", "receiving a newspaper" and "receiving a post". In these role playing activities children can mention the names of objects in connection with those encountered in the role play activities.

The construction game is done by the teacher by distributing game equipment to each child with different games from each other so that one child with other children can develop their own creativity and ultimately be more motivated to tell about the results of his work. The addition of time in the construction game is adjusted to the level of difficulty of the material it forms. The selection of game equipment is done from simple game forms to more complex game forms. The application is also done in stages starting from the small number of pieces to the number of more pieces. This construction game is intended to improve children's creativity and language abilities.

Thematic learning activities on the theme of communication tools, the teacher utilizes the class and all the contents in it that have been designed in such a way that is appropriate and related to the theme of communication tools. Colorful picture cards and word cards are hung and affixed to the panel boards placed on the left, right side, in front of and behind the class. The desire of children to be creative and tell stories more actively in class both tells about the pictures they see and tells about the pictures they make. The children ask each other questions and explain to the teacher and their friends about what they see. The ability of children to try to imitate letters and words and the desire to know the reading of words and simple sentences is higher.

The cognitive level of the child pictured in learning activities can be seen from the excitement and activity of the child when learning is carried out through play activities, for example seen in the child's expression beaming and his enthusiasm of the child inserting a picture card in the box provided by mentioning the name of the object or activity one one by one, then their spirits were also seen when spelling and reading simple words and sentences. In activities such as this, children get more vocabulary, both information they get from the teacher and those that they themselves also dig from their peers. The same thing happens when children enthusiastically ask questions about things they have seen / heard or intentionally demonstrated by the teacher, as well as when answering questions raised by the teacher.

The development of the child's cognitive level is done by the teacher by designing the class according to the theme carried, word cards and pictures hanging in the classroom and 
pasted on the panel board, including also presenting objects in their original form or in the form of models/miniatures. Children's creativity increases when the child can participate actively, the child does not only see word cards and picture cards, original objects or models/miniatures, but can observe, hold, play and work with these tools or objects. Children look enthusiastic observing, playing and working with these objects and ask the teacher and discuss with his friends about the objects he observed. Then the child is asked to tell stories or give opinions about these objects and there may be among children having direct experience related to these objects.

The child's cognitive development also develops when the child performs construction games such as forming images or buildings derived from puzzle pieces of images, plasticity and blocks. Children who first find the shape of a picture or have formed a building whether a rectangle, triangle, circle or other, then competing to come to the teacher to show the results of his work. By the teacher the child is asked to tell the work. Thus the creativity of children is formed and the ability of children's language is also formed at the same time.

Children's language skills are formed and improved from the child's mastery of simple words to more complex words. Enthusiastic children recognize letters, write letters, then spell them, then the ability to read increases with the number of children who start fluently reading words increases the percentage and subsequently the child is able to read simple words and sentences in a picture story book.

The urgency of thematic learning in improving children's abilities is emphasized by the Ministry of Education and Culture through Ministerial Regulation number 146 of 2014 concerning the 2013 Early Childhood Education Curriculum (2014) states that in implementing early childhood learning applying 10 (ten) principles, namely: (1) learning through play, (2) oriented to child development, (3) oriented to the needs of children, (4) centered on children, (5) active learning, (6) oriented to the development of character values, (7) oriented to developing skills life, (8) supported by a conducive environment, (9) oriented towards democratic learning, and (10) the use of learning media, learning resources, and resource persons.

The findings of this study that show children's cognitive and language levels increase through thematic learning support the findings of previous research conducted, among others: (1) Kartini and Waridah research (2018) on the implementation of thematic learning in early childhood education shows good results for children from aspects cognitive development. This thematic learning can be seen from the preparation of learning tools, in addition to the application of thematic learning in accordance with thematic principles, (2) Nasution et-al (2018) research shows that the implementation of thematic learning in group B has been going well. Supporting and inhibiting factors in thematic learning are emotional intelligence of early childhood is as expected, and (3) Ananda's research (2017) shows the technical implementation of the development of moral and religious values in children formally conducted 15-20 minutes every day before the activity learning begins with the form of activities using the lecture method (explaining concepts), through games, telling stories, singing, exemplary, role playing, field trips. 


\section{Conclusion}

The conclusions that can be drawn from the findings of this study are: (1) thematic learning planning conducted by Raudhatul Atfhal Rahmat Islamiyah Medan teacher by compiling the learning implementation plan at the beginning of the semester by referring to the applicable curriculum of Raudhatul Atfhal, (2) the implementation of learning the thematic at Raudhatul Atfhal Rahmat Islamiyah Medan is carried out with varied learning methods using various games such as name recall games, achievement games, motion games, construction games and also playing roles, and (3) evaluation of learning towards thematic learning at Raudhatul Atfhal Rahmat Islamiyah Medan by providing a portfolio, in this case behavioral changes are evaluated, children can also experience cognitive and language improvement after following the thematic learning process.

Suggestions that can be conveyed in connection with the findings of this study are: (1) to the head of Raudhatul Atfhal Rahmat Islamiyah Medan, should be able to meet a variety of facilities and infrastructure that is more complete and also facilitating teachers in developing better learning implementation plan by involving teachers in training conducted Ministry of Religion or other institutions, (2) to Raudhatul Atfhal Rahmat Islamiyah Medan teacher so that it can improve innovations in managing thematic learning through individual reading activities, attending training and seminars, so that thematic learning activities can be more interesting and enjoyable, and (3) to the next researcher, so that they can research about thematic learning outside the focus of the study examined in this study.

\section{References}

Allen, K. E., and Marotz, L.R. (2010). Developmental Profiles: Pre-Birth Through Twelve. Alihbahasa: Valentino. Profil Perkembangan Anak Prakelahiran Hingga Usia 12 Tahun, Jakarta; Indeks.

Ananda, Rizki. (2017). Implementasi Nilai-Nilai Moral dan Agama Pada Anak Usia Dini. Jurnal Obsesi Vol. 1 No. 1 Tahun.

Ananda, Rusydi., and Abdillah. (2018). Pembelajaran Terpadu. Karakteristik, Landasan, Fungsi, Prinsip Dan Model, Medan: Lembaga Peduli Pengembangan Pendidikan Indonesia (LPPPI).

Direktorat Pembinaan Pendidikan Anak Usia Dini Kementerian Pendidikan dan Kebudayaan, Kebijakan Pendidikan Anak Usia Dini Tahun 2016. Jakarta: Direktorat Pembinaan Pendidikan Anak Usia Dini Kementerian Pendidikan dan Kebudayaan.

Kartini dan Waridah. (2018). Implementasi Pembelajaran Tematik Pada Pendidikan Anak Usia Dini. Jurnal: Pendidikan dan Pemberdayaan Masyarakat. Vol. 5 No. 2 Tahun.

Moeslichatoen, R. (2004).Metode Pengajaran di Taman Kanak-Kanak, Jakarta: Rineka Cipta.

Nasution, Hikmatun Khoirina. (2018).Implementasi Pembelajaran Tematik. Dalam Perkembangan Kecerdasan Emosional Anak Usia Dini Kelompok B Di TK IT Nurul Ilmi Medan. Jurnal Raudhah. Vol. 06 No. 01 Januari-Juni.

Santrock, J.W. (2008).Educational Pyscerhology, Alihbahasa: Triwibowo B.S. Psikologi Pendidikan. Jakarta: Kencana Prenada Media Group.

Simorangkir, F. (2019). Implementation of Multiple Intelligences Approach Based On Batak Angkola Culture in Learning Thematic For Class IV SD Negeri 100620 Pargarutan Julu South Tapanuli District. Budapest International Research in Linguistics and Education Sciences (BirLE), P. 547-551. 
Sutirjo and Mamik, Sri Istuti, (2004)Tematik: Pembelajaran Efektif Dalam Kurikulum Malang: Bayumedia Publishing.

Tukimo, et al. (2005) Buku Pegangan Guru Perangkat Pembelajaran Tematik, Jakarta: Tekindo Utama.

Yamin, M. and Sanan, J.S. (2010). Panduan Pendidikan Anak Usia Dini, Jakarta: Gaung Persada Press.

Yus, Anita. (2011) Model Pendidikan Anak Usia Dini. Jakarta: Kencana Prenada Media Group. 